\title{
New Glaze Composition for Chemical Strengthening of Bone China
}

\author{
Hyeong-Jun Kim $*$, Yoon Soo Han*, Hyung-Bin Park $* * * *$, Jewon Park $* * *$, \\ Hyein Na****, and Sung-Churl Choi $* * *$ \\ *Korea Institute of Ceramics Engineering \& Technology, Icheon 17303, Korea \\ **Department of Materials Science and Engineering, Hanyang University, Seoul 04763, Korea
}

(Received March 15, 2018; Revised April 25, 2018; Accepted April 25, 2018)

\begin{abstract}
In order to improve the hardness of commercial bone china, we suggested a chemical strengthening process and new glaze for its process. New glaze contained about two times more $\mathrm{Na}_{2} \mathrm{O}$ and $\mathrm{Al}_{2} \mathrm{O}_{3}$ and had a higher transition temperature than that of commercial frit. Chemical strengthening enhanced the hardness of the new glaze-coated bone china by over $30 \%$ compared to that of commercial product. The change of glaze composition influenced potassium ion diffusion distance and depth of strengthened layer during chemical treatment. After chemical strengthening of new glaze-coated bone china, the residual compressive stress inside the glaze was measured and found to be greater than $160 \mathrm{MPa}$.
\end{abstract}

Key words : Bone china, Glaze, Residual stress, Chemical strengthening, Hardness

\section{Introduction}

$\mathrm{S}_{\mathrm{i}}^{\mathrm{i}}$ nce the invention of bone china by Thomas Frye in the UK in 1749, bone china has become a high quality ceramic ware. ${ }^{1)}$ Bone china production in Korea started in the 1970s, and the domestic quality level has now come to be on par with products manufactured in advanced nations. The material properties of bone china have continued to be improved since the 2000s through various efforts including the enhancement of the ingredient materials and glaze. ${ }^{2-8)}$

The Frit glaze used in bone china widely uses ABS (Advanced Borosilicates) without lead, including $\mathrm{B}_{2} \mathrm{O}_{3}-\mathrm{SiO}_{2}$, Bismuth-Silicate, and Zinc-Strontium. ${ }^{9-11)}$ Especially, the ABS glaze most used in Korea has been reported to have a low refractive index and less gloss compared to lead-based or bismuth glazes ${ }^{12)}$ however, these are difficult to distinguish with the naked eye.

With regard to chemical strengthening techniques, application research has been carried out with the aim of improving the surface hardness of dental crown products. ${ }^{13,14)}$ Recently, there have been efforts to enhance the surface hardness of bone china due to problems of hygiene, and research by Kim et al. reported the strengthening of glaze by varying the bone china curing conditions and applying chemical strengthening to regular ceramics. ${ }^{15-17)}$

In this study, as a follow up to a previous study, ${ }^{17)}$ new glaze compositions advantageous for chemical strengthening were proposed. Based on the degree of the improvement and the glass reinforcement mechanism, the presented glazes

\footnotetext{
${ }^{\top}$ Corresponding author : Hyeong-Jun Kim

E-mail : goldbud@kicet.re.kr

Tel : +82-31-645-1446 Fax : +82-31-645-1491
}

were analyzed to determine their improvement of the hardness through chemical strengthening.

\section{Experimental Procedure}

The glaze used for comparison in this study was the commercially available bone china glaze manufactured by $\mathrm{H}$ company. Although there was a restriction that the entire composition of the commercial glaze cannot be revealed, the contents of the core materials, $\mathrm{Al}_{2} \mathrm{O}_{3}$ and $\mathrm{Na}_{2} \mathrm{O}$, were 7.4 and $6.3 \mathrm{wt} \%$, respectively (Table 1). The composition of the Frit presented in this study was varied by increasing the $\mathrm{SiO}_{2}$ and $\mathrm{Al}_{2} \mathrm{O}_{3}$ contents with the prediction that the resulting product would be stronger in comparison to a glass structure. The $\mathrm{Na}_{2} \mathrm{O}$ content was more than double that of the reference commercial Frit. Compared to other alkaline earth oxides, $\mathrm{CaO}$ addition was disadvantageous for chemical strengthening, so the $\mathrm{CaO}$ content was decreased to less than about $1 / 3$ in comparison to that of the commercial product. ${ }^{18)}$ The thermal expansion coefficient of the glaze was set at $9.3 \times 10^{-6} /{ }^{\circ} \mathrm{C}\left(50 \sim 500^{\circ} \mathrm{C}\right)$, similar to that of the body.

The Frit glaze is composed only of glass, so plasticity and adhesive strength are lacking; thus, a small amount of inorganic binder was included to compensate for the lacking properties. The inorganic binder was composed of clay such as Kaolin and Bentonite. When an inorganic binder is added, the glass transition temperature $\left(\mathrm{T}_{\mathrm{g}}\right)$, dilatometeric softening point $\left(\mathrm{T}_{\mathrm{dsp}}\right)$, and half-sphere temperature $\left(\mathrm{T}_{1 / 2}\right)$, observed by high temperature microscope, slightly increase for the glaze. This phenomenon was thought to be due to the increased $\mathrm{SiO}_{2}$ and $\mathrm{Al}_{2} \mathrm{O}_{3}$ content from the inorganic binder in the Frit. Table 1 shows the composition and thermal 
properties of the body and glaze.

The mixture of the Frit and inorganic binder was glazed on a 10 inch dish through spray coating, followed by curing for $3 \mathrm{~h}$ at the curing temperature of $1100^{\circ} \mathrm{C}$. The curing was carried out in the commercial tunnel kiln at $\mathrm{H}$ company. The lead-free Frit glaze for the bone china underwent vitrification in advance to produce a powder unlike that of regular glaze, so the vitrification reaction occurred conveniently through high temperature heat treatment of the Frit and inorganic binder mixture, producing the glaze layer.

In order to investigate the chemical strengthening effect of bone china, the specimens were chemically strengthened in a chemical strengthening reactor at 420,450, 480, and $510^{\circ} \mathrm{C}$ for 3,6 , and $12 \mathrm{~h}$ each using a $100 \% \mathrm{KNO}_{3}$ melt. The specimens for chemical strengthening were prepared by cutting the flat portion at the center of the 10 inch plates into dimensions of $20 \times 20 \mathrm{~mm}^{2}$.

The hardness of the bone china glaze was measured using a micro hardness tester (Shimadzu, HMV 2T E, Japan). In order to determine the residual stress within the glaze, the specimens were processed to a thickness of $0.2 \mathrm{~mm}$, followed by mirror surface finishing on both sides. The residual stress was measured using a polarizing microscope (Nikon, Optiphot-POL, Japan) and an automatic strain viewer (HanKook Lab, HKL-HPASM-S200, Korea). The glass transition temperature and coefficient of thermal expansion were measured using a Thermomechanical Analyzer (TA, TMA Q400, U.S.A). After the chemical strengthening, the $\mathrm{K}^{+}$ion penetration depth and concentration were measured using EDS (Energy Dispersive spectroscopy, Oxford, Aztec, UK).

\section{Results and Discussion}

Figure 1 shows the chemical strengthening results of the ceramic specimens with the various glaze compositions and chemical strengthening temperatures. The newly proposed glaze for chemical strengthening was found to result in hardness improvements of more than approximately $30 \%$ compared to the case of the commercial glaze. In the case of composition $\mathrm{X}, 12 \mathrm{~h}$ chemical strengthening at $480^{\circ} \mathrm{C}$ come to a maximum value of $8.46 \mathrm{GPa}$; the hardness of the commercial glaze was $6.3 \mathrm{GPa}$.

The hardness of the glaze before chemical strengthening was around $6.3 \sim 6.5 \mathrm{GPa}$, which was similar to that of the commercial product $(6.3 \mathrm{GPa})$. Since $\mathrm{Al}_{2} \mathrm{O}_{3}$ is already known to strengthen the glass structure and improve its hardness, ${ }^{19-22)}$ the increase in the $\mathrm{Al}_{2} \mathrm{O}_{3}$ content for the proposed glaze was predicted to result in hardness improvement before strengthening. However, because the $\mathrm{Na}_{2} \mathrm{O}$ content increased simultaneously, this effect was thought to be diminished.

For the chemical strengthening at $420^{\circ} \mathrm{C}$, which temperature is lower than the glass transition temperature, the hardnesses of the new glaze compositions increased according to time (Fig. 1(a) and (b)). This result showed that the stress within the glass continued to increase during the dispersion of potassium ions. Although the commercial product

Table 1. Compositions of Body and Glaze of Bone China

$(\mathrm{wt} \%)$

\begin{tabular}{|c|c|c|c|c|c|c|c|c|c|}
\hline & & \multicolumn{2}{|c|}{$\mathrm{X}$} & \multicolumn{2}{|c|}{$\mathrm{Y}$} & \multicolumn{2}{|c|}{$\mathrm{Z}$} & \multicolumn{2}{|c|}{$\operatorname{Ref}^{+}$} \\
\hline & $\mathrm{SiO}_{2}$ & \multicolumn{2}{|c|}{60.5} & \multicolumn{2}{|c|}{61.0} & \multicolumn{2}{|c|}{59.0} & \multicolumn{2}{|c|}{$\star$} \\
\hline & $\mathrm{Al}_{2} \mathrm{O}_{3}$ & \multicolumn{2}{|c|}{13.0} & \multicolumn{2}{|c|}{12} & \multicolumn{2}{|c|}{10.0} & \multicolumn{2}{|c|}{7.4} \\
\hline & $\mathrm{B}_{2} \mathrm{O}_{3}$ & \multicolumn{2}{|c|}{2.0} & \multicolumn{2}{|c|}{2.0} & \multicolumn{2}{|c|}{3.0} & \multicolumn{2}{|c|}{$\star$} \\
\hline & $\mathrm{CaO}$ & \multicolumn{2}{|c|}{2.0} & \multicolumn{2}{|c|}{3.0} & \multicolumn{2}{|c|}{3.0} & \multirow{3}{*}{\multicolumn{2}{|c|}{ RO $20(\star)$}} \\
\hline & $\mathrm{MgO}$ & \multicolumn{2}{|c|}{3.0} & \multicolumn{2}{|c|}{2.0} & \multicolumn{2}{|c|}{3.0} & & \\
\hline & $\mathrm{ZnO}$ & \multicolumn{2}{|c|}{5.5} & \multicolumn{2}{|c|}{5.5} & \multicolumn{2}{|c|}{5.5} & & \\
\hline & $\mathrm{Na}_{2} \mathrm{O}$ & \multicolumn{2}{|c|}{12.0} & \multicolumn{2}{|c|}{13} & \multicolumn{2}{|c|}{13} & \multicolumn{2}{|c|}{6.3} \\
\hline & $\mathrm{K}_{2} \mathrm{O}$ & \multicolumn{2}{|c|}{2.0} & \multicolumn{2}{|c|}{1.5} & \multicolumn{2}{|c|}{1.5} & \multirow{2}{*}{\multicolumn{2}{|c|}{$\mathrm{R} 2 \mathrm{O} 6.0(\star)$}} \\
\hline & $\mathrm{Li}_{2} \mathrm{O}$ & \multicolumn{2}{|c|}{-} & \multicolumn{2}{|c|}{-} & & & & \\
\hline & & & & & & & & & \\
\hline & Frit / Frit+Binder & $\mathrm{F}$ & $\mathrm{F}+\mathrm{B}$ & $\mathrm{F}$ & $\mathrm{F}+\mathrm{B}$ & $\mathrm{F}$ & $\mathrm{F}+\mathrm{B}$ & $\mathrm{F}$ & $\mathrm{F}+\mathrm{B}$ \\
\hline & $\begin{array}{l}\mathrm{CTE} \times 10^{-6} /{ }^{\circ} \mathrm{C} \\
\left(100-300^{\circ} \mathrm{C}\right)\end{array}$ & 9.7 & 8.3 & 9.1 & 7.3 & 9.3 & 8.5 & 8.2 & 7.9 \\
\hline Therm. & $\operatorname{Tg}\left({ }^{\circ} \mathrm{C}\right)^{*}$ & 592 & 648 & 598 & 615 & 584 & 618 & 481 & 494 \\
\hline & $\mathrm{T}_{\mathrm{dsp}}\left({ }^{\circ} \mathrm{C}\right)^{* *}$ & 627 & 696 & 632 & 653 & 618 & 656 & 535 & 544 \\
\hline & $\mathrm{T}_{1 / 2}\left({ }^{\circ} \mathrm{C}\right)^{* * *}$ & 1009 & 1134 & 1015 & 1079 & 989 & 1061 & 950 & 1012 \\
\hline
\end{tabular}

\footnotetext{
+ Commercial Frit

* Tg : Glass Transition Temperature $\left(10^{13.3} \text { Poise }\right)^{29)}$

** $\mathrm{T}_{\text {dsp }}$ : Dilatometric Softening Point $\left(10^{11.3} \text { Poise }\right)^{30)}$

*** $\mathrm{T}_{1 / 2}$ : Half Sphere Temperature measured by High Temp. Microscope $\left(10^{4.6} \text { Poise }\right)^{30}$

$\star$ : Unable to publish
} 
showed a similar tendency, change in the hardness plateaued over time when the chemical strengthening temperature was above $450^{\circ} \mathrm{C}$. This result was determined to be due to the chemical strengthening temperature approaching the glass transition temperature of $560^{\circ} \mathrm{C}$ for the commercial glaze. However, for the new glaze compositions with high glass transition temperatures, it was observed that the hardness steadily increased with time even for the chemical strengthening at $480^{\circ} \mathrm{C}$. Except for composition X, after $3 \mathrm{~h}$ the chemical strengthening at $510^{\circ} \mathrm{C}$ showed a decreasing trend rather than an increasing one for the other composition glazes (Fig. 1(d)). It was determined that relaxation phenomenon did not occur because the glass transition temperature of the composition $\mathrm{X}$ glaze was relatively higher than those of the two other compositions $;{ }^{20)}$ the transition temperature difference resulted from the difference in the alumina content.

Figure 2 shows the change of depth of layer according to various chemical strengthening temperatures and times. It has been reported that during the fabrication of chemically strengthened glass, the chemical strengthening depth or depth of layer (DOL) mostly increase when the chemical strengthening temperature and time are increased. ${ }^{20,23)}$ In order to investigate this effect, the $\mathrm{K}^{+}$ion penetration depth within the glass was examined using EDS line scanning; Fig. 3 shows the results for the chemical strengthening case at $450^{\circ} \mathrm{C}$. As can be observed in each image, the $\mathrm{K}^{+}$ion dispersion depth increased with time. It was found that the $\mathrm{K}^{+}$ dispersion depth due to chemical strengthening increased with time. According to Nordberg et al., the rate of $\mathrm{K}^{+}$dispersion is proportional to $\mathrm{t}^{1 / 2} .^{24)}$ Also, the dispersion depth abides by the general Arrhenius equation, and so the depth increases as the temperature increases. ${ }^{25)}$ Despite this, the occurrence of the stress relaxation phenomenon, in which the hardness decreases as the chemical strengthening temperature increases, was due to the viscous behavior near the transition temperature. ${ }^{20}$ ) This phenomenon signifies the existence of an industrially optimal processing time and temperature. Thus, for the glaze proposed in this study, in terms of the appropriate strengthening temperature and time, the optimal processing conditions appear to be $480^{\circ} \mathrm{C}$ and $3 \sim 6 \mathrm{~h}$.

The hardness variation with respect to the temperature for the fixed chemical strengthening time of $3 \mathrm{~h}$ is shown in Fig. 4. Compared to the commercial glaze, the proposed glaze for chemical strengthening was found to improve the

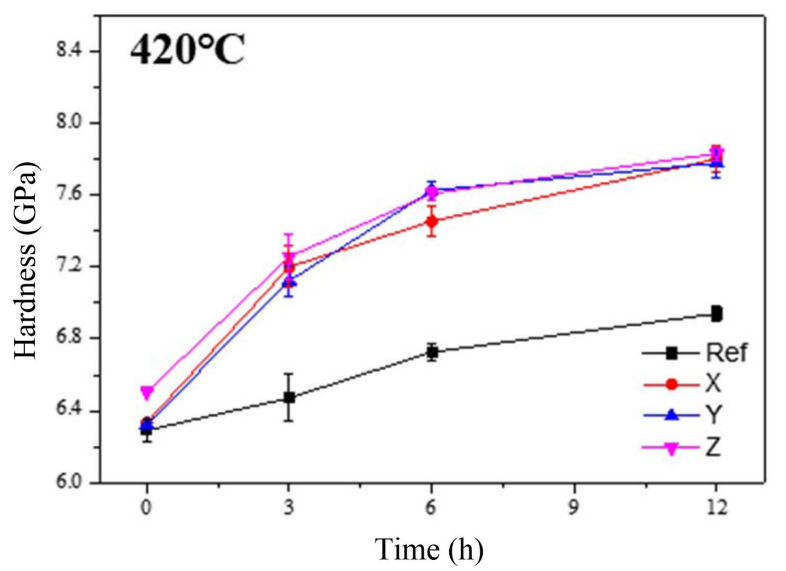

(a)

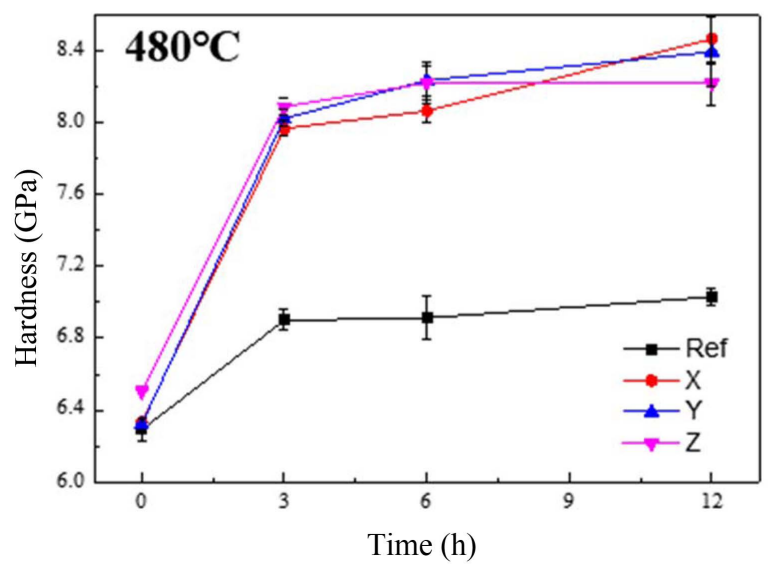

(c)

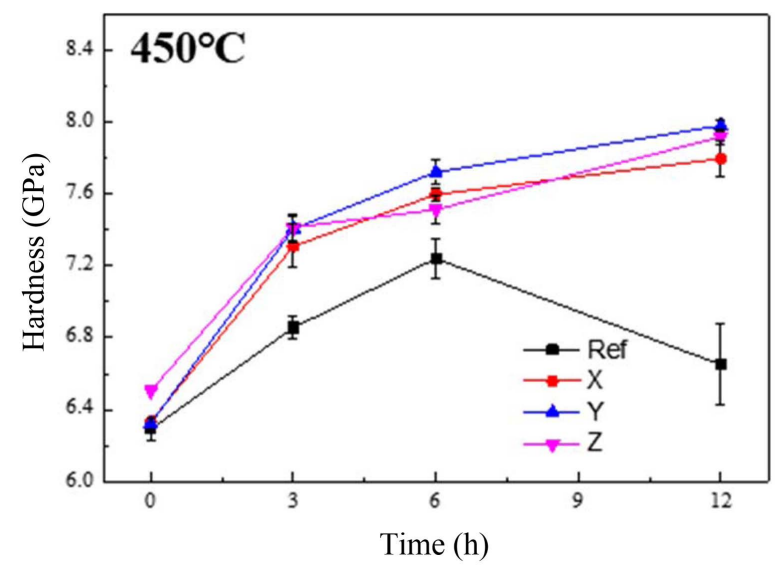

(b)

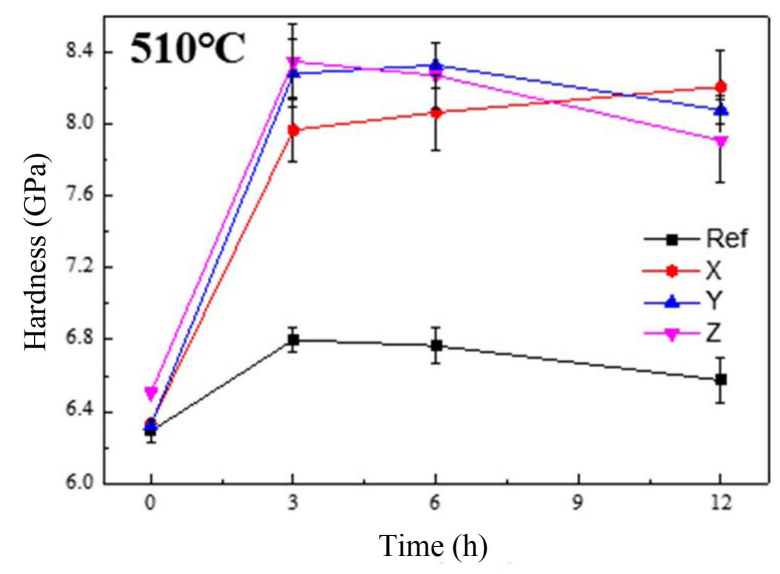

(d)

Fig. 1. Change of hardness according to chemical treatment temperatures and times. 


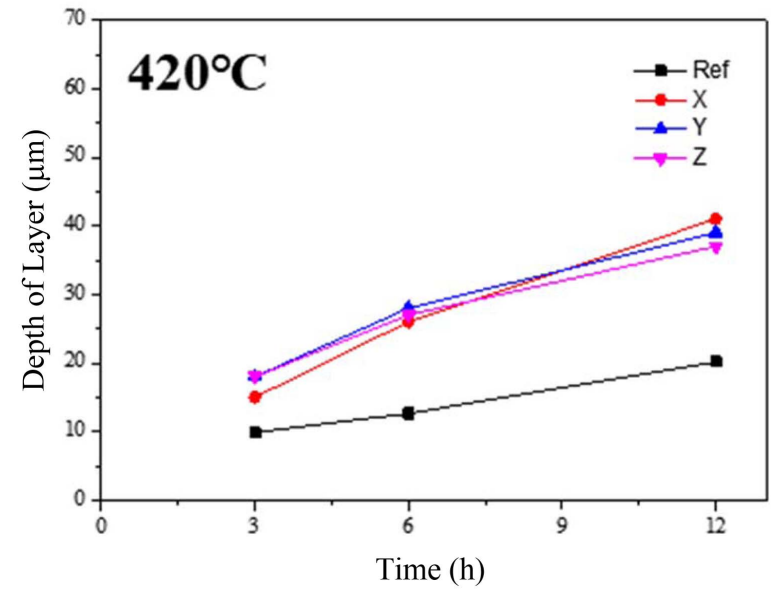

(a)

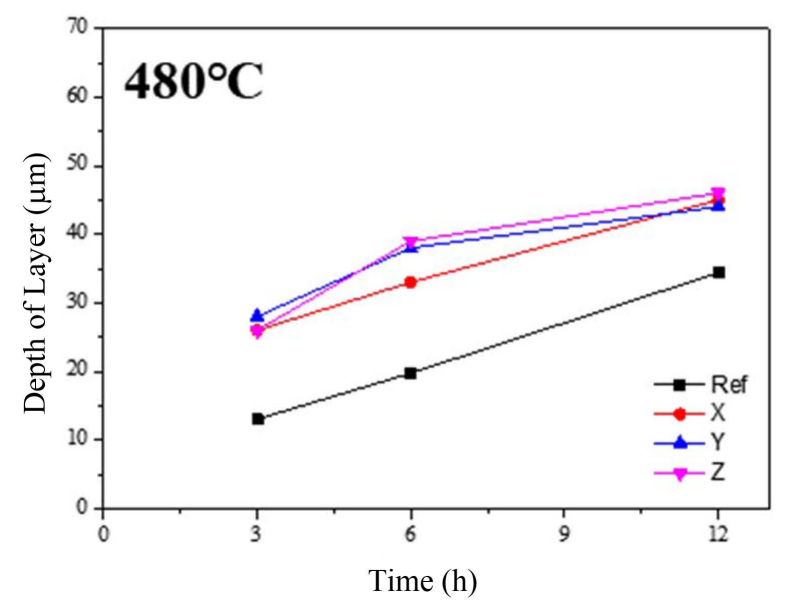

(c)

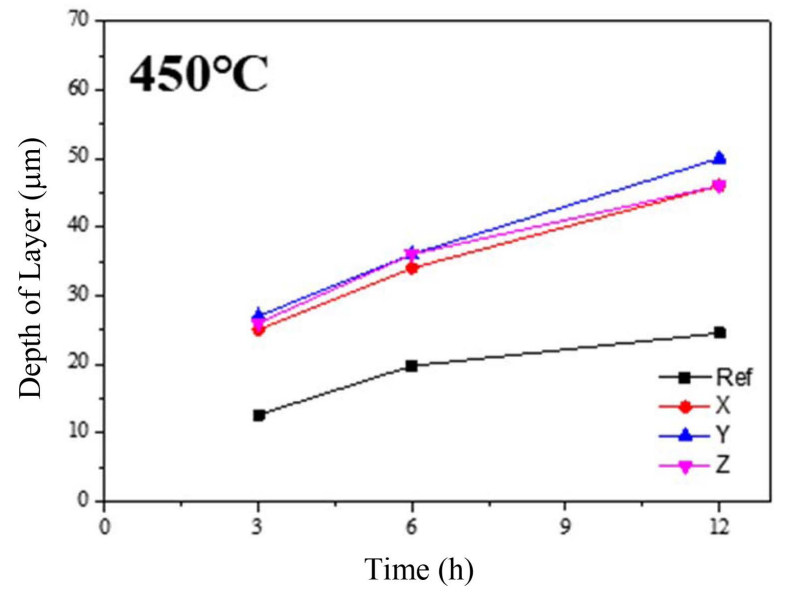

(b)

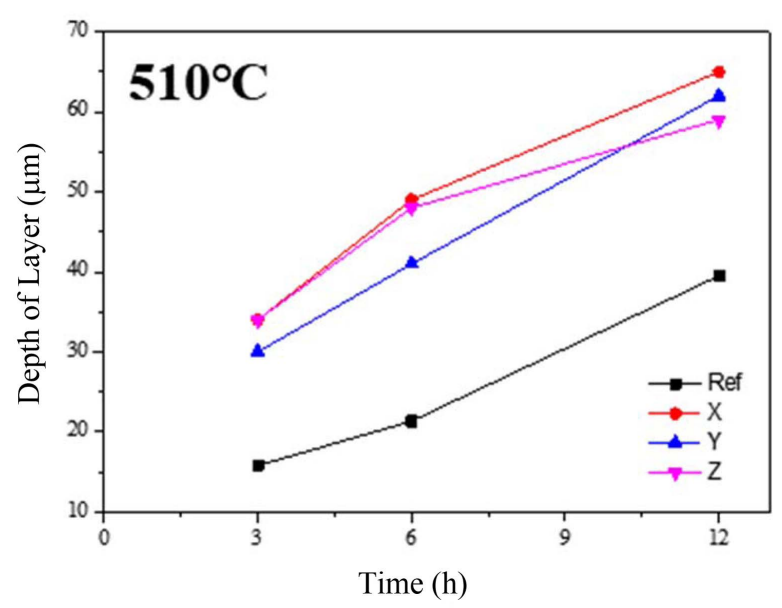

(d)

Fig. 2. Change of depth of layer according to various chemical strengthening temperatures and times.

hardness by more than $30 \%$. In the case of composition $\mathrm{X}$, a hardness of approximately $8.3 \mathrm{GPa}$ was obtained through chemical strengthening at $510^{\circ} \mathrm{C}$ for $3 \mathrm{~h}$, while the hardness of the commercial glaze was $6.3 \mathrm{GPa}$.

The increase in the hardness through chemical strengthening was thought to be due to an increase in the internal stress. Fig. 5 shows polarized microscope images of the newly proposed glaze and commercial glaze specimens after chemical strengthening. As can be observed in the figure, the newly proposed glaze can be observed to have four different colors, representing the glaze layer surface, glaze layer center, reaction boundary layer between the glaze and body, and the body. Fig. 6 shows observation results obtained using an automatic strain viewer for the residual stress of specimen $\mathrm{X}$, which underwent chemical strengthening at $480^{\circ} \mathrm{C}$ for $12 \mathrm{~h}$. As can be observed, the compressive strength of the surface layer (approximately $162.8 \mathrm{MPa}$ ) is clearly shown and the tensile stress of the reaction boundary layer can be observed. For the commercial product that did not undergo chemical strengthening, a stress of 43.3 MPa was obtained using the thermal expansion coefficient difference between the glaze and body, according to Eq. (1), ${ }^{26)}$ shown below.

$$
\sigma_{g /}=E\left(T_{0}-T_{1}\right)\left(\alpha_{g /}-\alpha_{b}\right)
$$

Here, $\sigma_{\mathrm{g} 1}$ : residual stress within the glaze, E : Young's modulus of the glaze, $\mathrm{T}_{0}$ : temperature with no residual stress within the glaze, $\mathrm{T}_{1}$ : new temperature, $\alpha_{\mathrm{gl}}$ : thermal expansion coefficient of the glaze, $\alpha_{b}$ : thermal expansion coefficient of the body

As found in the previous study, compressive stress is generated in bone china glaze due to the reaction boundary layer, which has a high thermal expansion coefficient. ${ }^{16)}$ Currently, the needle-like boundary layer was predicted to be anorthite $\left(\mathrm{CaO} \cdot \mathrm{Al}_{2} \mathrm{O}_{3} \cdot 2 \mathrm{SiO}_{2}\right)$, with a very high thermal expansion coefficient of around $15 \sim 16 \times 10^{-6} /{ }^{\circ} \mathrm{C} .{ }^{27)}$ Figs. 7 and 8 show the microstructure and EDS composition analysis results for specimen $\mathrm{X}$. The needlelike phase was also observed through a polarized microscope and was found to have a relatively higher $\mathrm{Al}_{2} \mathrm{O}_{3}$ content compared to the glass layer; the needlelike phase did not contain any $\mathrm{Zn}$ component. Additionally, calcium phosphate particles were observed. 


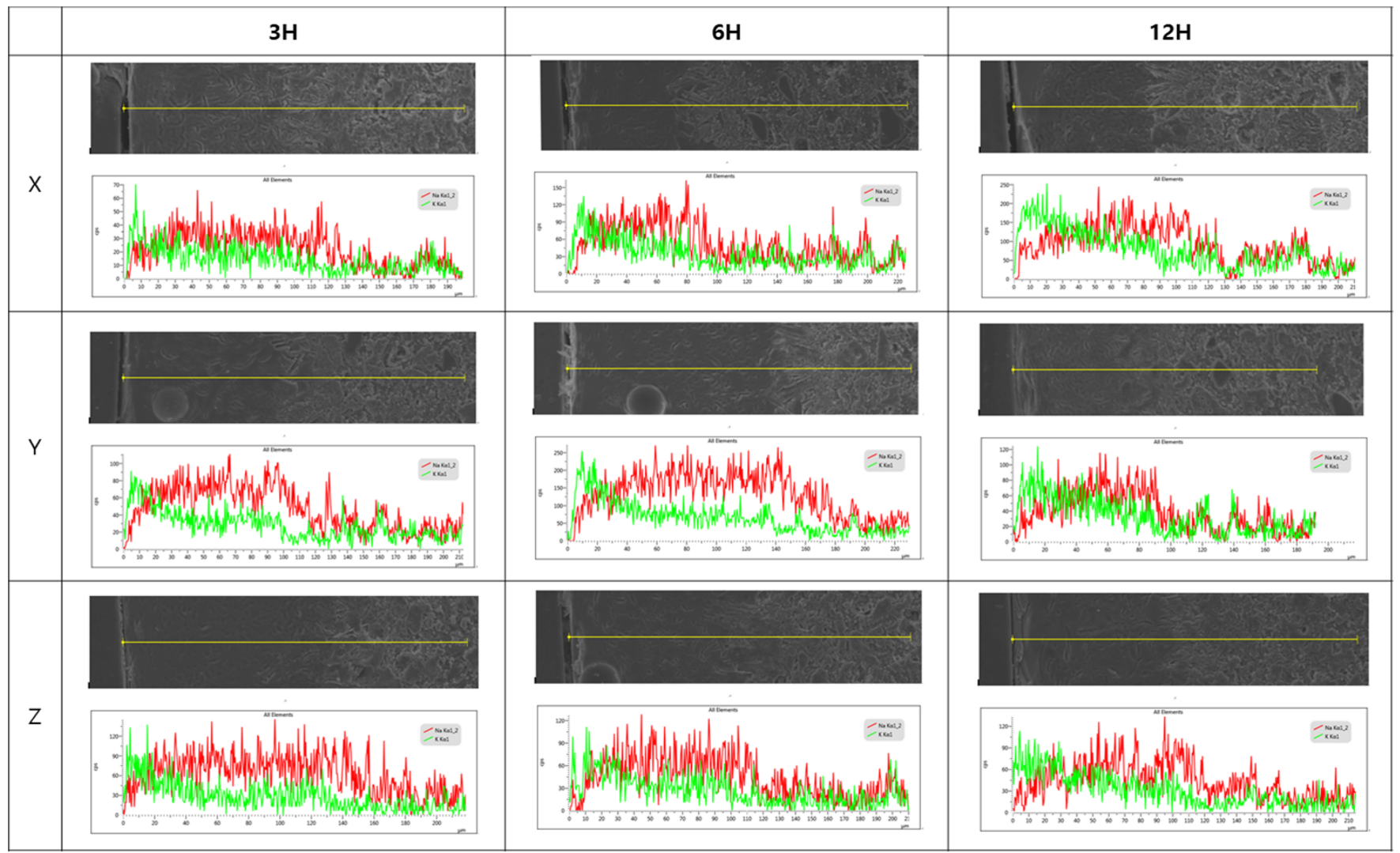

Fig. 3. Depth profile of potassium and sodium according to chemical strengthening times at $450^{\circ} \mathrm{C}$.

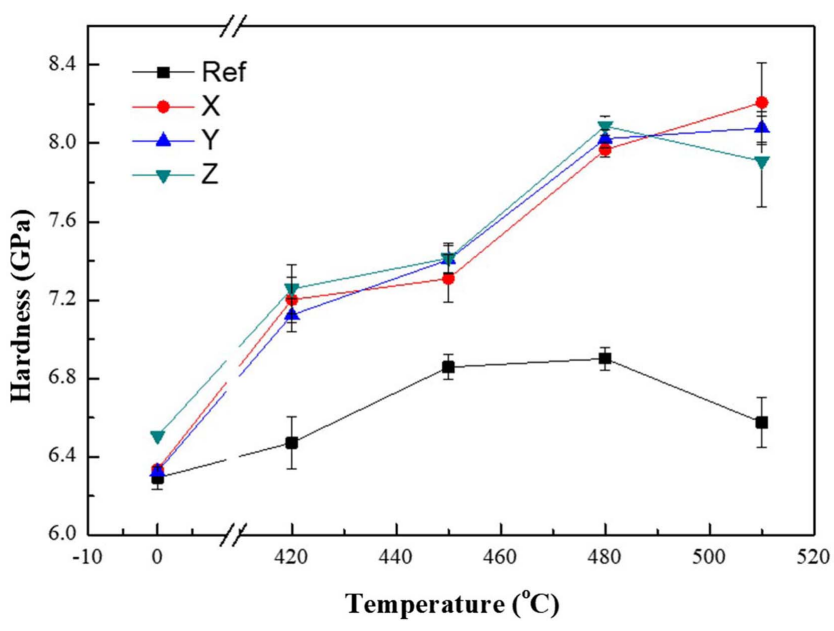

Fig. 4. Change of hardness according to chemical strengthening temperatures for $3 \mathrm{~h}$.

According to the report of Ichiko, this was predicted to be hydroxyl apatite, with a very high thermal expansion coefficient of around $14 \times 10^{-6} /{ }^{\circ} \mathrm{C}$.

On the other hand, for the commercial product (Fig. 7(a)), the reaction boundary layer was not observed to form. Its cause was predicted to be due to one of the following: 1) the temperature was too low to induce crystallization because the curing temperature of the commercial product was low at about $1100^{\circ} \mathrm{C}$ or 2) the $\mathrm{Al}$ content within the commercial Frit was relatively low. For the newly proposed glaze, the $\mathrm{Al}_{2} \mathrm{O}_{3}$ content was high at over $40 \%$ and the Ca concentration was relatively low in the glaze compared to the body, dispersing the Ca ion into the glaze and providing an advantage for the formation of a reaction boundary layer between the glaze and body.

The previous study revealed that sufficient curing of the bone china glaze at $1200^{\circ} \mathrm{C}$ produced a calcium phosphate compound and Anorthite layer with a large thermal expansion coefficient in the middle layer between the glaze and body, increasing the surface compressive stress of the glaze layer during the cooling process. However, the maximum effect obtained through the curing temperature increase resulted in a hardness increase of only about 5\%. Another method of ceramic hardness enhancement was to form low thermal expansion crystalline phases in the glaze. ${ }^{28)}$ However, it is difficult to apply to bone china, because its glaze loses glossy.

Therefore, the glaze for chemical strengthening proposed in this study was expected to provide the basis for obtaining a high hardness product while maintaining the transparency of the bone china glaze.

\section{Conclusions}

In order to improve the surface hardness of high-quality 


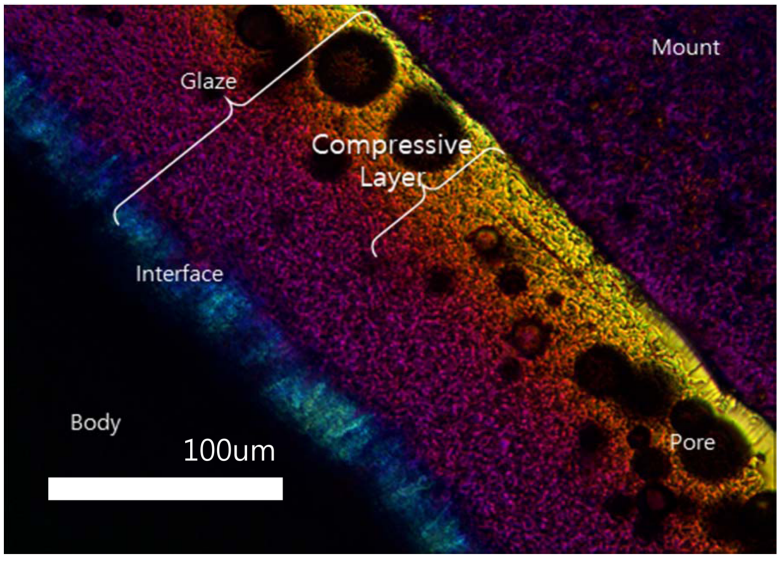

(a)

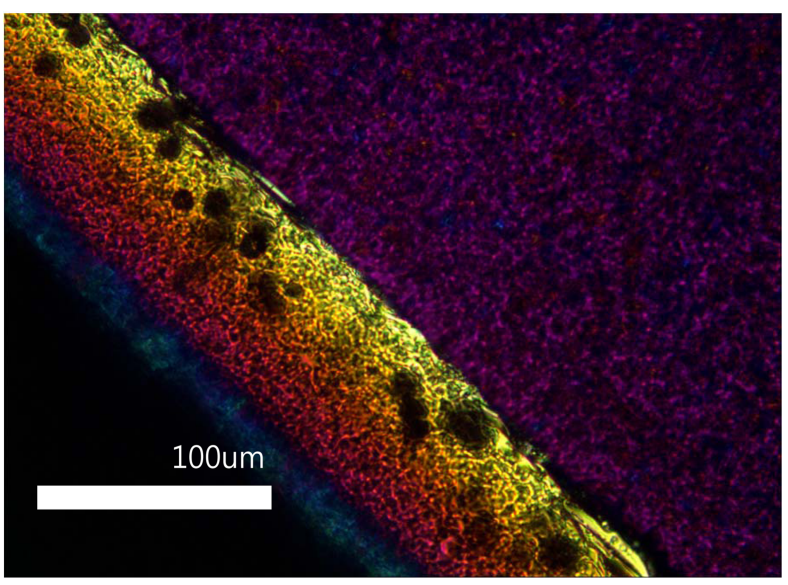

(c)

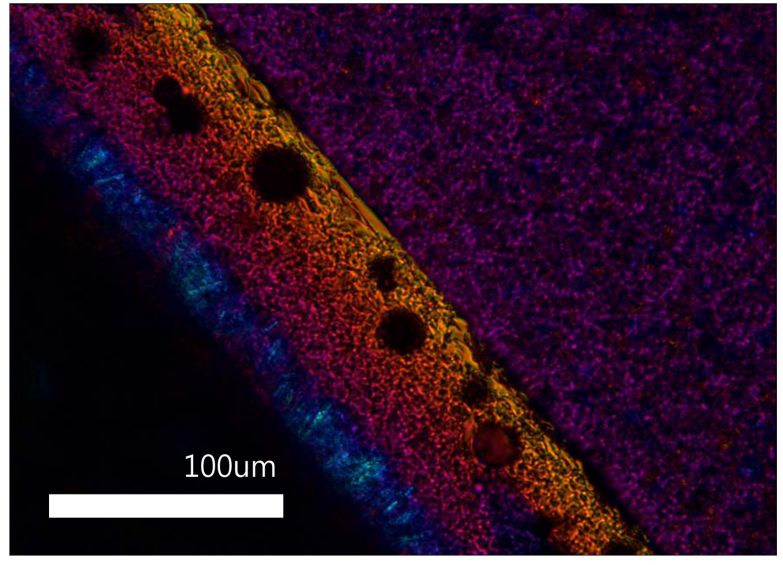

(b)

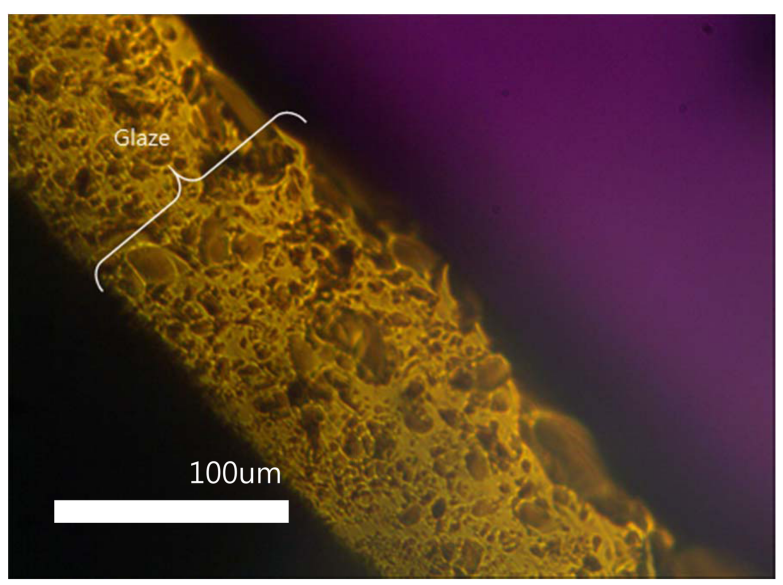

(d)

Fig. 5. Polarizing micrographs of glaze layer section (X400): (a) sample $\mathrm{X}$, (b) $\mathrm{Y}$, (c) $\mathrm{Z}$ strengthened chemically at $480^{\circ} \mathrm{C}$ for $12 \mathrm{~h}$ and (d) commercial product without treatment.

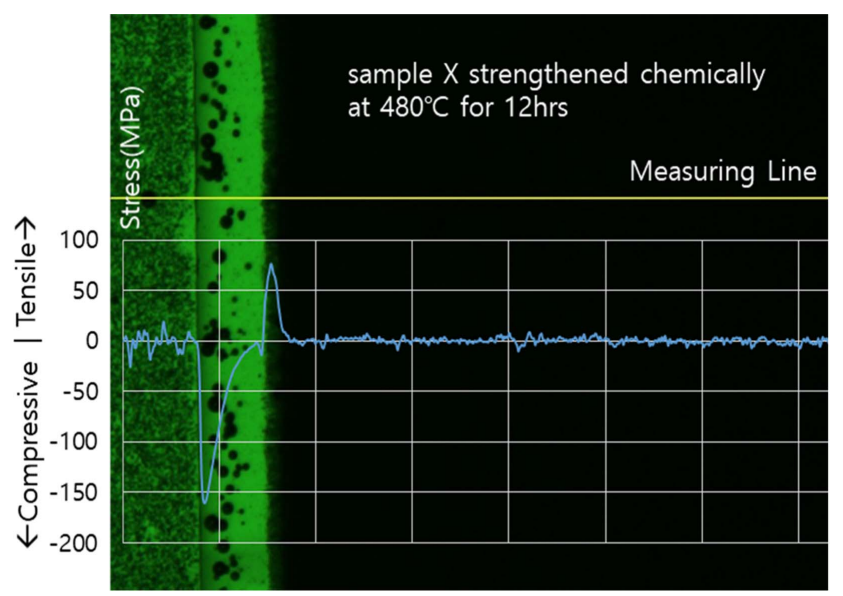

(a)

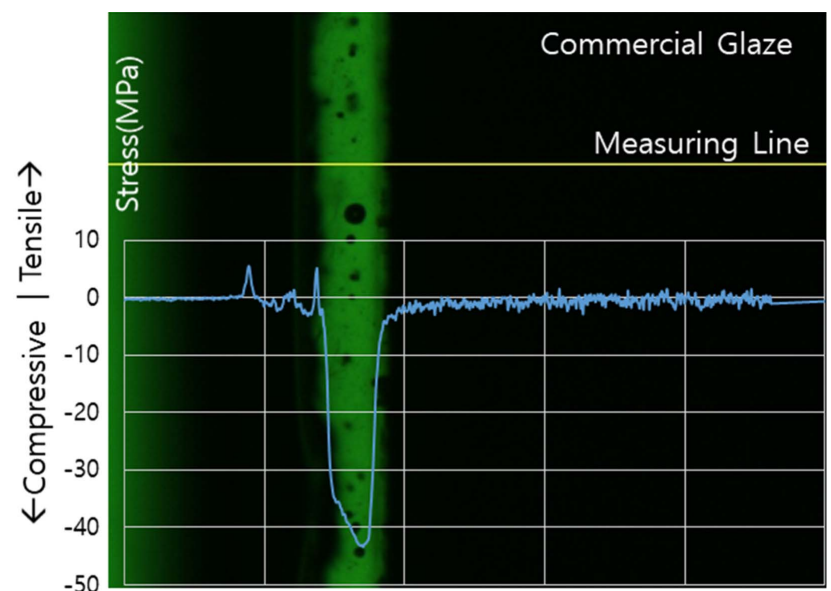

(b)

Fig. 6. Residual stress in the glaze layer section: (a) sample $\mathrm{X}$ strengthened chemically at $480^{\circ} \mathrm{C}$ for $12 \mathrm{~h}$ and (b) commercial product without treatment.

ceramic bone china, a new glaze composition for effective chemical strengthening was proposed.

The proposed glaze doubled the amounts of $\mathrm{Na}_{2} \mathrm{O}$ and
$\mathrm{Al}_{2} \mathrm{O}_{3}$ for chemical strengthening. Chemical strengthening of the bone china with the proposed glaze applied resulted in a hardness improvement of more than $30 \%$. The optimal 


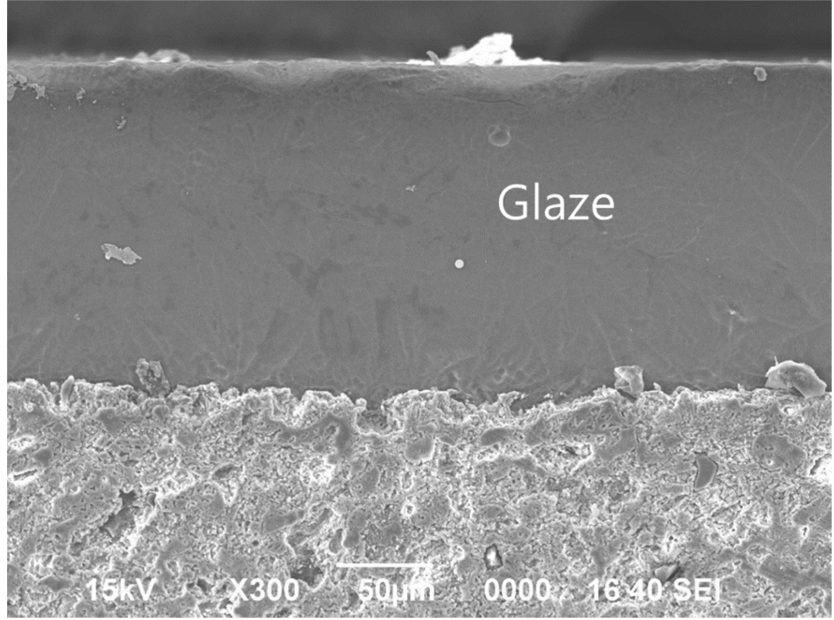

(a)

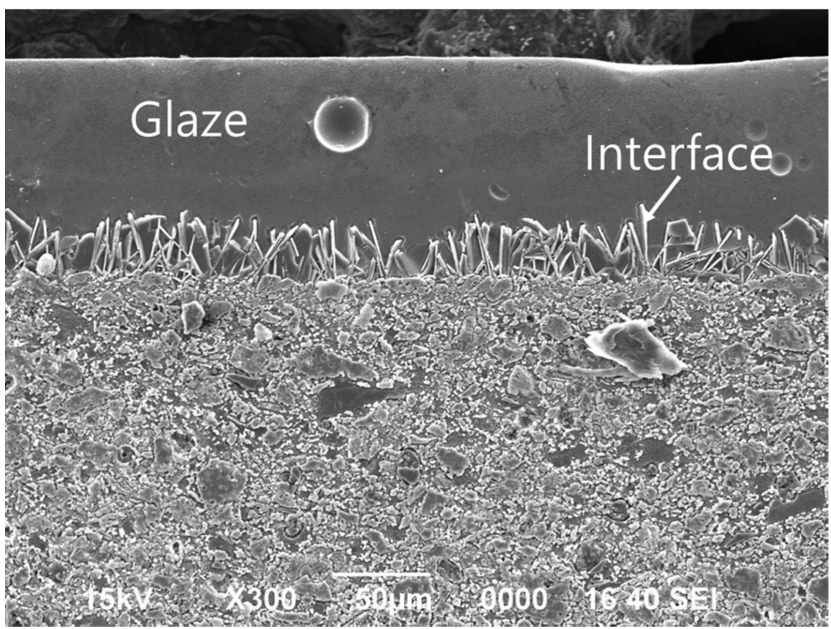

(b)

Fig. 7. Microstructures of glaze layer sections of (a) commercial product without treatment and (b) sample X.

conditions for chemical strengthening of $480^{\circ} \mathrm{C}$ for $12 \mathrm{~h}$ or $510^{\circ} \mathrm{C}$ for $3 \mathrm{~h}$ were expected to be sufficient to reach the highest property values.

Although a chemically strengthened layer of greater than $40 \mu \mathrm{m}$ was formed through the chemical strengthening process, chemical strengthening with excessive temperature increases or extended time durations resulted in a decreasing hardness trend, and this was in agreement with the case of general chemically strengthened glass. The surface compressive stress obtained through chemical strengthening was more than $160 \mathrm{MPa}$, which was a hardness increase of more than 3 times the compressive stress due to the thermal expansion between the glaze and body.

\section{Acknowledgments}

This work was supported by the Development of Other Technology Program (Grant No.: 10070453) funded By the Ministry of Trade, Industry and Energy (Korea).
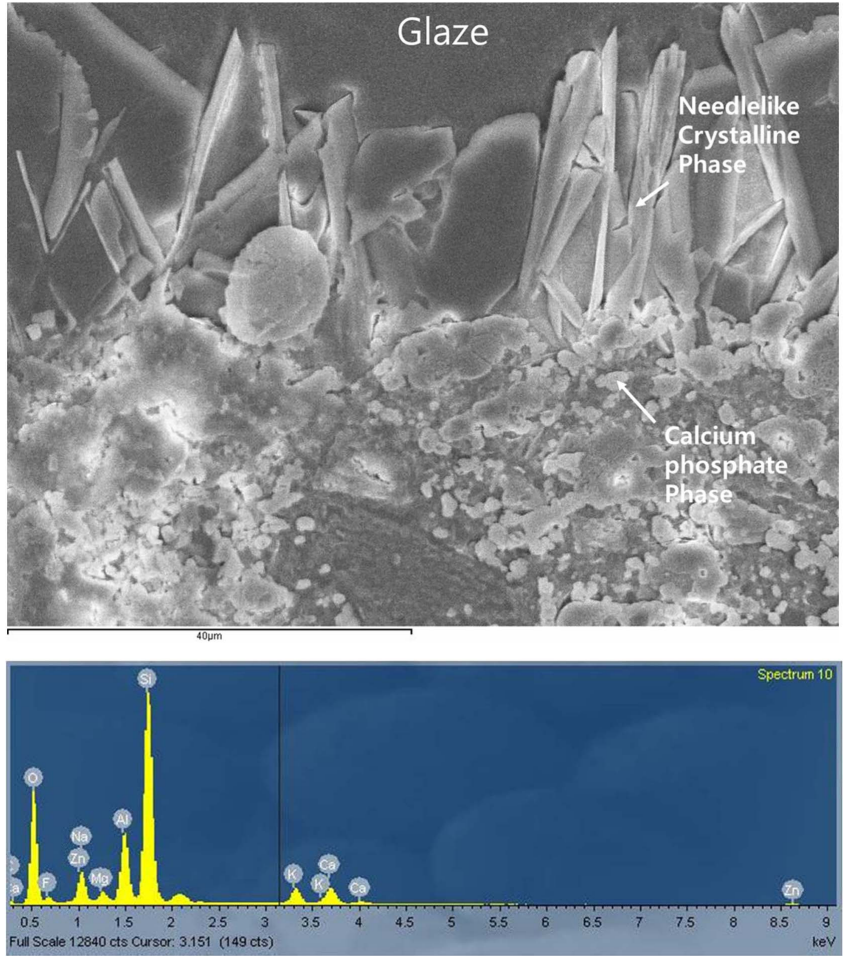

(a)

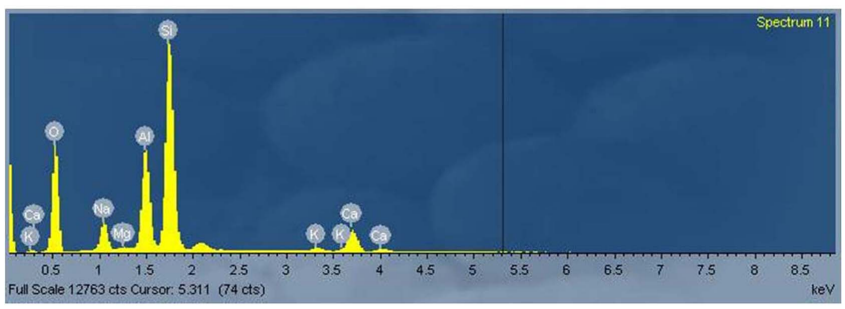

(b)

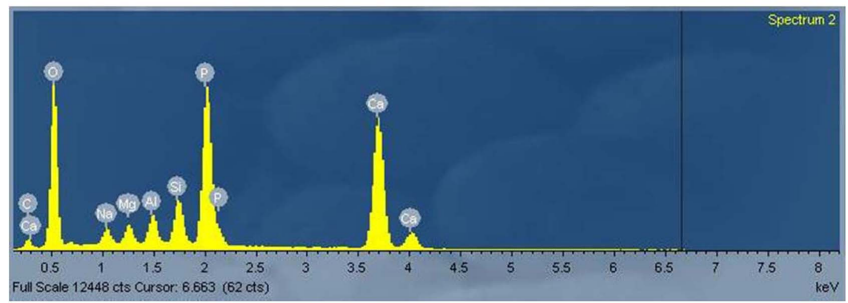

(c)

Fig. 8. EDS results of the $\mathrm{X}$ glaze layer sections: (a) glaze, (b) needlelike crystalline phase and (c) calcium phosphate phase.

\section{REFERENCES}

1. W. R. H. Ramsay, K. Sutton, and E. G. Ramsay, "Bow Porcelain: Glaze Compositions Associated with the Phosphatic Ware 1742-1774," Proc. R. Soc. Victoria, 123 [2] 161-71 (2004).

2. S. A. F. Batista, P. F. Messer, and R. J. Hand, "Fracture Toughness of Bone China and Hard Porcelain," Br. Ceram. Trans., 100 [6] 256-59 (2001). 
3. S. R. Braganca, C. P. Bergmannm, and H. Hubner, "Effect of Quartz Particle Size on the Strength of Triaxial Porcelain," J. Eur. Ceram. Soc., 26 [16] 3761-68 (2006).

4. G. Stathis, A. Ekonomakou, C. J. Stournaras, and C. Ftikos, "Effect of Firing Conditions, Filler Grain Size and Quartz Content on Bending Strength and Physical Properties of Sanitary Ware Porcelain," J. Eur. Ceram. Soc., 24 [8] 2357-66 (2004).

5. A. D. N. Junior, D. Hotza, V. C. Soler, and E. S. Vilches, "Analysis of The Development of Microscopic Residual Stresses Particles in Porcelain Tile," J. Eur. Ceram. Soc., 28 [14] 2629-37 (2008).

6. X. Cheng, S. Ke, Q. Wang, H. Wang, A. Shui, and P. Liu, "Characterization of Transparent Glaze for Single-Crystalline Anorthite Porcelain," Ceram. Int., 38 [6] 4901-8 (2012).

7. D. U. Tulyaganov, S. Agathopoulos, H. R. Fernandes, and J. M. F. Ferreira, "The Influence of Incorporation of ZnOcontaining Glazes on the Properties of Hard Porcelains," J. Eur. Ceram. Soc., 27 [2] 1665-70 (2007).

8. C. B. Ustundag, Y. K. Tur, and A. Capoglu, "Mechanical Behavior of A Low-Clay Translucent White Ware," J. Eur. Ceram. Soc., 26 [1-2] 169-77 (2006).

9. E. D. Spinosa and K. J. Davies, "Lead-Free Glaze or Enamel for Use on Ceramic Bodies"; US Patent 5,447,891 A (September 29, 1993).

10. Y. Tokunaga, "Lead-free Frit Glaze"; US Patent 5,362,687 A (February 4, 1992).

11. R. O. Knapp, "Low-Temperature Lead-Free Glaze for Alumina Ceramics"; US Patent 5,677,250 (October 17, 1994).

12. A. Kara and R. Stevens, "Interactions between an ABS Type Leadless Glaze And a Biscuit Fired Bone China Body During Glost Firing. Part II: Investigation of Interactions," J. Eur. Ceram. Soc., 22 [7] 1103-12 (2002).

13. V. Rosa, H. N. Yoshimura, M. M. Pinto, C. Fredericci, and P. F. Cesar, "Effect of Ion Exchange on Strength and Slow Crack Growth of a Dental Porcelain," Dent. Mater., 25 [6] 736-43 (2009).

14. K. J. Anusavice, C. Shen, and R. B. Lee, "Strengthening of Feldspathic Porcelain by Ion Exchange and Tempering," J. Dent. Res., 71 [5] 1134-38 (1992).

15. D. H. Kim, J. H. Maeng, Y. S. Han, H. T. Kim, S. C. Choi, and H. J. Kim, "The Mechanical Properties of Porcelain with Thermally and Chemically Induced Residual Stress on Glaze,” J. Korean Ceram. Soc., 51 [5] 487-91 (2014).
16. H. J. Kim, D. H. Kim, D. M. Kim, J. H. Choi, Y. S. Han, S. M. Lee, and H. T. Kim, "The Generation of the Residual Stress in ABS Type Glaze of Commercial Bone China," $J$. Eur. Ceram. Soc., 36 [3] 899-903 (2016).

17. H. J. Kim, Y. S. Han, D. H. Kim, D. M. Kim, J. H. Choi, S. M. Lee, Y. Kim, and H. T. Kim, "Improvement of Glaze Hardness in Commercial Bone China," J. Korean Ceram. Soc., 52 [6] 508-13 (2015).

18. Y. Nagashima, "Strengthening of Glass and its Structure; from Viewpoints of Fracture and Chemical Strengthening Performance (in Japanese)," New Glass, 30 [114] 3-10 (2015)

19. S. Inaba and S. Fujino, "Mechanical Properties of Glass (in Japanese)," New Glass, 23 [4] 46-52 (2008).

20. Y. Nagashima, "Chemically Strengthened Glass - from View Point Glass for Mobile Display (in Japanese)," New Glass, 26 [1] 5-10 (2011).

21. M. B. Volf, Chemical Approch to Glass; pp. 300-1, Elsevier, Amsterdam, 1984.

22. H. Scholze, Glass; pp. 272-73, Springer-Verlag, New York, 1991.

23. J. H. Maeng, Chemical Strengthening of Soda-Lime Sheet Glass (in Korean)", pp. 40-6, in Ph.D. Thesis, Hanyang University, Seoul, 2014.

24. M. E. Nordberg, E. L. Mochel, H. M. Garfinkel, and J. S. Olcott, "Strengthening by Ion Exchange," J. Am. Ceram. Soc. 47 [5] 215-19 (1964).

25. R. Gy, "Ion Exchange for Glass Strengthening," Mater. Sci. Eng., B, 149 [2] 159-65 (2008).

26. W. D. Kingery, "Factors Affecting Thermal Stress Resistance of Ceramic Materials," J. Am. Ceram. Soc., 38 [1] 315 (1955).

27. M. Tribaudino, R. J. Angel, F. Camara, F. Nestola, D. Pasqual, and I. Margiolaki, "Thermal Expansion of Plagioclase Feldspars," Contrib. Mineral. Petrol., 160 [6] 899908 (2010)

28. S. Ghosh, K. S. Pal, N. Dandapat, J. Ghosh, and S. Datta, "Glass-Ceramic Glaze for Future Generation Floor Tiles," J. Eur. Ceram. Soc., 33 [5] 935-42 (2013).

29. M. Ahmed and D. A. Earl, "Characterizing Glaze-Melting Behavior via HSM," Am. Ceram. Soc. Bull., 81 [3] 47-51 (2002).

30. J. Partyka, K. Gasek, K. Pasiut, and M. Gajek, "Effect of Addition of $\mathrm{BaO}$ on Sintering of Glass-Ceramic Materials from $\mathrm{SiO}_{2} \cdot-\mathrm{Al}_{2} \mathrm{O}_{3}-\mathrm{Na}_{2} \mathrm{O}-\mathrm{K}_{2} \mathrm{O}-\mathrm{CaO} / \mathrm{MgO}$ System," J. Therm . Anal. Calorim., 125 [3] 1095-103 (2016). 